\title{
Influence of Quality of Clinical Learning Environment on the Development of Nursing Students' Professional Identity
}

\author{
Eman M. Elhosieny ${ }^{1}$, Wafaa A. Elhosany ${ }^{2}$, Marwa M. Abdel Aleem ${ }^{3}$ \\ Faculty of Nursing, Port Said University \\ Nursing Administration department, Suez Canal University
}

\begin{abstract}
Background: Professional identity has ended up as vital challenges regarding education in faculty of nursing. Aim: The aim of the current research is examine the Influence of clinical learning quality on the development of nursing students' professional identity. Subjects and Methods: There was descriptive correlational research design. This research has been applied in Port Said University. All nursing students at third and fourth academic year were included. Data collected using one tool consisted of three parts: A Self structured questionnaire data sheet, Learning Environment Scale and professional identity scale. Results: The result revealed that: about two thirds of students (67\%) perceived their environment as low effective learning environment and more than four fifth of students (93\%) had positive professional identity.The study results recommended that: Faculty member should encourage students to be interested by social problems associated with nursing.
\end{abstract}

Key words: Clinical Learning Environment, professional identity, nursing student. 


\section{INTRODUCTION}

The environment of clinical learning is a complicated process which affects students' learning. Discovering this environment pays attention to the educational role of the clinical areas and enhances the chances for students to learn (Kroger \&Marcia, 2011).

Dunn, Ehrich and Mylonas,(2000) indicated that clinical environment(CE) provide opportunities for students to learn how to apply theory to practice, and to become socialized into the expectations of the employment setting and health professions colleagues, later, Papp, Markkanen, and von Bonsdorff, (2003) added that CE consists of all that surrounds the student, including setting, equipment, clinical staff, patients and educators; the learning environment is therefore an important element in the whole learning process.

Many factors may influence students in their clinical learning environment as staff nurse, peers, faculty and the patient (Kathleen \& Colleen, 2013). Moreover, the support given to students by the nursing staff in the clinical setting, also, has a crucial role in the achievement of learning objectives (Chaun\& Barnett, 2012).

In this respect, Kilcullen, (2007) studied the effectiveness of staff nurses on clinical learning and it was indicated that students who received constructive feedback from the nurse reflected enhanced analytic skills and socialization in the clinical setting. Regarding peer influence Black, (2012) asserted that, peer groups provide a forum where students construct and reconstruct their identities.

In relation to faculty effect, the encouraging of frequent student and faculty contact has generally been considered one of good practice of undergraduate education (Strayer \& Beitz, 2010). According to Henning, Shulruf, Hawken\& pinnock, (2011) students have reported the supervisory relationship is most important factor influencing their satisfaction with the clinical learning environment.

Concerning patient effect, the positive relation between nurse and patient is very important, and it must be stressed. Therefore, a good experience of caring can be gained from the relationship between nursing student and patient. By meeting the needs of the patients, students need to become aware of their own self and of their own feelings and reactions, especially in new or challenging situations (Suikkala \& Leino-Kilpi, 2010). 
There is great effect of the clinical learning environment on nursing student's perception of their profession and facilitates professional grounding (McKenna, McCall \& Wray, 2010). Moreover, Crigger and Godfrey (2012) asserted that knowledge, value, skills, behaviors and value relevant and appropriate to professional nursing practice are acquired over time through interactive and repetitive processes.

\section{Significance of the study:}

Professional identity is an important challenge which provides many services to nursing education (Nikbakht, Nasrabadi \& Emami, 2006). From my past history when I am student I found that student constructed their identity from contact in learning environment. Nurses' identities are constructed through their institutional belonging and the exercise of particular roles in the context of professional practices. Thus, the aim of the current research is determining the relation between nursing learners' perceptions of environmental influences and the professional identity the students developed.

\section{THE AIM OF STUDY:}

\section{The aim of the current research is to:}

Examine effectiveness of clinical learning environment on developing nursing students' professional identity.

\section{The research questions:}

- What is the students' perception about attributes of clinical learning environment?

- What is the students' attitude towards nursing profession?

- What is the relation between the perception of clinical environment and the professional identity?

\section{SUBJECTS AND METHODS:}

Descriptive correlational research design was used to achieve study objectives.

\section{Settings:}

This research was conducted in Port Said University, Nursing faculty.

\section{Subjects:}

Study subjects include all nursing students at third and fourth academic year with the total sample of 195 nursing students: third year 104 students and fourth year 91 students at academic year 2015-2016.

\section{Tools:}

One tool consisted of three parts was designed: 
- Part I:

- A Self structured questionnaire data sheet to elicit

a) Student personal and academic characteristics as name, age, grade....etc

b) General student profile as: choice of nursing, degree obtained, presence of a nurse in family

- Part II:

- Learning Environment Scale this tool developed by Dalme (1983) and translated into Arabic language by Saber (1995) aiming at assessing clinical learning environment as perceived by nursing students and factors influencing learning environment and divided into 3 factors as following:

1- Faculty influences (19 items)

2- Staff nurse influences (21 items)

3- Peer influences (21 items)

Another subscale will be added for student-patient relation adopted from Dunn and Burnett (1995)

Scoring system: The points strongly agree and agree were merged to reflect positive attitude of students toward their clinical learning environment and strongly disagree and disagree were merged to reflect negative attitude of students toward their clinical learning environment.

The scores of students' perception towards CLE and factors influencing it was estimated as following:

\begin{tabular}{|c|c|c|c|c|}
\hline Faculty Influence & $\begin{array}{c}\text { Staff Nursing } \\
\text { Influence }\end{array}$ & Peer Influence & $\begin{array}{c}\text { Student patient } \\
\text { Relation }\end{array}$ & $\begin{array}{c}\text { Total Perception of } \\
\text { Clinical Learning } \\
\text { Environment }\end{array}$ \\
\hline Low (84-115) & Low (78-105) & Low (78-105) & Low (16-20) & Low (238- 325) \\
Moderate (52- & Moderate (50-77) & Moderate (50- & Moderate (10- & Moderate (152- \\
$83)$ & High (21-49) & $77)$ & $15)$ & $237)$ \\
High (19-51) & & High (21-49) & High (4-9) & High (65- 151) \\
& & & & \\
\hline
\end{tabular}

\section{Part III:}

This part Developed by Dalme (1983) and translated into Arabic language by Saber (1995) aiming at measuring professional identity of nursing students 9 items.

Student was considered had high professional identity if the percent score was $60 \%$ or more and low if less than $60 \%$. 


\section{Content validity:}

Study tool was tested by a panel of 5 expertise in nursing field (nursing administrationmedical surgical -community and psychology) and modification was done accordingly (correct translation and no items were omitted).

\section{Reliability :}

Tool reliability was tested by cronbach alpha test, and it was as following

\begin{tabular}{|l|c|c|}
\hline \multicolumn{1}{|c|}{ Component } & Items & $\begin{array}{c}\text { Cronbach Alpha } \\
\text { Test }\end{array}$ \\
\hline 1.Clinical Learning Environment & 65 & 0.959 \\
\hline Subscale & & 0.922 \\
\hline -Peer Influence & 21 & 0.932 \\
\hline -Academic Staff Influence & 19 & 0.939 \\
\hline -Nursing Staff Influence & 21 & 0.693 \\
\hline -Patient Relation Influence & 4 & 0.818 \\
\hline 2.Professional Identity & 9 & \\
\hline
\end{tabular}

\section{The Pilot study:}

$10 \%$ of students were included after developing the tools and after defining the time.

\section{Fieldwork:}

This study conducted in Faculty of Nursing, Port Said University. Data has been collected for 3 months, throughout the period from February to April 2016. The researcher collect data once a week during was depriving and problem solving sessions at the beginning of the session. The tool was distributed, fills and collected at the same day. In each class the researcher explain the aim of study to students. Students filled in the questionnaire by themselves in the presence of the researcher to answer any questions that students might have about the questionnaire and ensure the objectivity of the responses and to check that all items were answered. The time needed to fill this questionnaire was 20-30 minute.

\section{Ethical Considerations}

Aim of study was explained to students before taking their permission to participate. Students were informed about the privacy of information obtained from them, the nature of study and right to withdraw. 


\section{STATISTICAL DESIGN}

Data were extracted from the questionnaire and computerized in Microsoft Excel 2010. Results were analyzed through many statistical methods and t-test was also integrated. The mean scores and standard deviation were calculated. Qualitative variables were compared using chi square test (X2) as the test of significance and the p-value is the degree of significant and using the spearman correlation test and correlation test $(r)$. A significant level value was considered when $p$-value $\leq 0.05$ and a highly significant level value was considered when $\mathrm{p}$-value $\leq 0.001$, while $\mathrm{p}$-value $>0.05$ indicates nonsignificant results.

\section{RESULTS:}

\section{The results are as follow:}

Attributes of clinical learning environment as perceived by nursing students (table 1).

Total score of professional identity among studied nursing students (table 2).

Correlation between clinical learning environment and professional identity (table 3).

Table (1): the table illustrates that more than four fifths of students perceived that academic staff had moderate effect to create positive clinical learning environment, while, slightly half of student agree that peer and nursing staff has no effect and less than two thirds of them agree that patient relation has no effect on creating positive CLE. As indicated in table, more than two third of students perceived that their CLE as low effective environment.

Table (2): As shown in table $92.8 \%$ of students had positive professional identity.

Table (3): As reported in table there is a statistical significant positive correlation between total clinical learning environment and professional identity. 
Table (1): Clinical learning environment attributes as perceived by studied nursing students $(n=195)$.

\begin{tabular}{|l|c|c|c|c|c|c|c|}
\hline \multirow{2}{*}{ Subscale } & \multicolumn{2}{|c|}{ Agree } & \multicolumn{2}{c|}{ Uncertain } & \multicolumn{2}{c|}{ Disagree } & \multirow{2}{*}{$\begin{array}{c}\text { Mean } \\
\text { (SD) }\end{array}$} \\
\cline { 2 - 7 } & No & $\%$ & No & $\%$ & No & $\%$ & \% \\
\hline Peer Influence & 3 & 1.5 & 92 & 47.2 & 100 & 51.3 & $\begin{array}{c}\mathbf{4 6 . 5 3} \\
(\mathbf{1 4 . 5})\end{array}$ \\
\hline Academic Staff Influence & 3 & 1.5 & 34 & 17.8 & 158 & 81.0 & $\begin{array}{c}\mathbf{4 1 . 3 6} \\
(\mathbf{1 3 . 3})\end{array}$ \\
\hline Nursing Staff Influence & 7 & 3.6 & 90 & 46.2 & 98 & 50.3 & $\begin{array}{c}\mathbf{4 8 . 2 8} \\
(\mathbf{1 5 . 0})\end{array}$ \\
\hline Patient Relation Influence & 5 & 2.6 & 63 & 32.3 & 127 & 65.1 & $\begin{array}{c}\mathbf{8 . 7 0} \\
(\mathbf{2 . 9 1})\end{array}$ \\
\hline Total Score (CLE) & 5 & 2.6 & 124 & 63.6 & 66 & 33.8 & $\begin{array}{c}\mathbf{1 6 5 . 7} \\
(\mathbf{4 0 . 7}\end{array}$ \\
\hline
\end{tabular}

Table (2): Total score of professional identity among studied nursing students $(n=195)$.

\begin{tabular}{|l|c|c|c|c|}
\hline \multirow{2}{*}{ Variables } & \multicolumn{3}{|c|}{ Total Score of Professional Identity } \\
\cline { 2 - 5 } & \multicolumn{2}{|c|}{ positive } & \multicolumn{2}{c|}{ negative } \\
\cline { 2 - 5 } & No & $\%$ & No & $\%$ \\
\hline Total Score & 181 & 92.8 & 14 & 7.2 \\
\hline Mean (SD) & \multicolumn{4}{|c|}{$19.78(5.99)$} \\
\hline Median & \multicolumn{4}{|c|}{19.0} \\
\hline
\end{tabular}

Table (3): Correlation between clinical learning environment and professional identity $(n=195)$.

\begin{tabular}{|l|c|c|}
\hline \multirow{2}{*}{ Clinical Learning Environment } & \multicolumn{2}{c|}{ Professional Identity } \\
\cline { 2 - 3 } & $\mathrm{r}$ & $\mathrm{p}$-value \\
\hline Peer Influence & 0.457 & $0.000^{* *}$ \\
\hline Academic Staff Influence & 0.454 & $0.000^{* *}$ \\
\hline Nursing Staff Influence & 0.592 & $0.000^{* *}$ \\
\hline Patient Relation Influence & 0.608 & $0.000^{* *}$ \\
\hline Total & 0.727 & $0.000^{* *}$ \\
\hline
\end{tabular}

$* * \mathbf{p} \leq \mathbf{0 . 0 0 1}$ 


\section{DISCUSSION:}

Learning environment is one of the critical components of learning experience. Delivering an effective, stimulating and high quality learning experience for students is central part of every university mission that its achievement is crucial to the institution success (Donald, 1996). Moreover, the goal of nursing education and training is the preparation of nursing students for a professional role, the clinical environment provides important role in this preparation (Midgley, 2006).

Regarding clinical learning environment effectiveness, this study showed that students perceived their environment as low effective environment The results of this study was in the same line with Musa (2017) who found that the majority of the students' opinions about their clinical learning environment were negatively to all factors.

Results from numerous studies done by Lofmark (2001); Foley, (2002); Chan, (2003). Regarding peer influence in clinical learning environment, the study finding revealed that about half of the students' reported that peers had no effect on clinical learning environment. This is a result of no mutual cooperation between colleagues, colleagues are not helpful in the formulation of proposals in nursing care and as a group and they not work seriously to become an excellent nurses. This result may be related to the students in obligatory education did not encourage to work as a team and learn to work individually and competitively. In this respect, Couper (2011) stated that team work can provide excellent learning, as the students can learn and gain experience in team work and participatory learning.

Concerning academic staff influence, the current study illustrated that four fifths of nursing students agreed that the academic staff had moderate effect on CLE, this as a result of faculty members encourage students to be interested by social problems associated with nursing in society, develop critical thinking and ability to solve problems and give students opportunities for training on nursing.

This results not agreed with, Atkins and Williams (1995)who found that the lack of collegial support is one of the factors affect the learning of the nursing students and in a study conducted by Gamel (2006) to determine the image of nursing as a profession among undergraduate nursing students and interns in Egypt, it was concluded that there is a great percentage of nursing students negatively influenced by faculty members due to a negative teacher-student relationship and lack of affection between them . 
This results congruent with Abdel El-Halem, El Hawashy, Gamal El-Dein and Tahain (2011), who studied the undergraduate male nursing students' perception about the image of the nursing profession and did not support this aspect and illustrated that nursing students were positively influenced by clinical training, this may be due to the development of their interactions with clinical instructors.

In relation to the most influential factors for students leaning in the clinical area according to Murphy, Rosser \& Bevan (2012) is staff nurse, staff nurses had no influence on CLE, this as a result of no help was found from staff nurse when needed and no appreciation to students from nursing staff in hospital when have done a good job. Overcrowded from students nurse in the units and lack of time for staff nurse to teach students and nurses' perception that students will be in higher position than them after graduation.

These results were congruent with Gray and Smith (2000) who discovered that inadequate feedback from a staff nurse mentor was viewed as a negative behavior that inhibited the learning experience of the student. Often the lack of feedback was attributed to staff nurses who were viewed as unwilling to offer praise or afraid of hurting the students' feelings. Papp, Markkanen and Von Bonsdorff (2003) asserted that the staff nurse was vital in providing the support students needed to accomplish students' educational goals during a clinical experience.

Regarding patient influence, this study denote that there is no influence from patient on students in CLE, this as a result of the first priority was given to task and patients' needs is not in the first priority. This results can explained by students want to finish their tasks and assignment in clinical field regarding anything else with no attention to the patients, and some of patients had aggressive behavior against student and refused to receive the care from them. This results is not congruent with Taha (2015) who found that nearly half of student is respected by the patient and their relatives.

Regarding nursing students' attitudes toward nursing profession, nursing student had positive professional attitudes towards nursing profession. This may be as a result of concerning about professional identity development during professionalization process through education and the importance was placed on self-image as core concept of professional identity.

This result is not congruent with Taha (2015) who found highest percentage of nursing student perceived that the nursing image is negative among the community. Also, Belete, 
Lamaro and Henok (2015) who found that $50 \%$ of student nurse had unfavorable attitude towards nursing profession. The study results congruent with Miligi and Selim (2013) who found the attitudes of Saudi nursing students tended to be positive towards nursing profession. Moreover, AlJarrah (2013) who found positive perceptions about the image of the nursing profession in Jordan. Furthermore, Saleh (2016) who study the professional identity and organizational commitment among nurses and found that the majority of studied nurses had high professional identity level and the professional image had the highest mean score of professional identity.

According to Wuest (1994) added that the ideas of subservience, passivity, and obedience historically were part of the socialization into nursing. For example, the idea of unquestioning obedience meant that nurses followed order and did what they were told. This value defeats the ideas of autonomy, self-regulation, and self-control. Moyer (1996) had conducted a study at Widener University U.S.A about "the relationships among sense of coherence, self-esteem and self-perception of clinical competence in junior and senior baccalaureate nursing students". This study revealed that most of junior and senior baccalaureate nursing students in the USA had a self-esteem that could be linked positively to improve self-perception of clinical competence and nursing image as a profession.

The results of this study found significance correlation between clinical learning environment and professional identity. This finding congruent with Saber (1995) who found that positive correlation between educational environment and professional identity.

\section{CONCLUSION:}

In the light of study results, it was concluded that two thirds of students perceived their environment as low effective learning environment. While, more than four fifth of students had high professional identity. Moreover, the study results concluded that a statistically positive correlation was found between clinical learning environment and professional identity.

\section{RECOMMENDATIONS:}

Based on the findings the following points are recommended:

\section{Recommendation for Faculty of Nursing:}


Faculty member should encourage students to be interested by social problems associated with nursing.

Encourage students to work as a team seriously to become an excellent nurse.

\section{Recommendation for Hospital Administration:}

Encourage nursing staff to give a sense of support to nursing student as dealing with students equally as adult professional

\section{Further studies are suggested:}

- Studies should be done to examine Factors influencing professional identity.

- Replicate the study on the larger sample to examine the influence of CLE on PI.

\section{REFERENCES:}

Abdel El-Halem, G.E., El Hawashy, Z.I., Gamal El-Dein, A.A. \& Taha, E.E., (2011). Undergraduate Male Nursing students' Perception about the Image of the Nursing Profession. Journal of American Science; 7(3):614-23

Al Jarrah, I.A. (2013). Associate nursing students' perceptions toward nursing profession in Jordan. European Scientific Journal; 1.9 (6): 1857 - 7881

Atack, L. M., Comacu, R., Kenny, N. \& Miller, D. (2000). Student and staff relationships in a clinical practice model: Impact on learning. Journal of Nursing Education, 39(9), 387-395.

Belete, A., Lamaro, T. \& Henok, A. (2015). Assessment of Attitudes towards Nursing Profession among Nurses and Non-Nursing Health Professionals Working in Mizan-Aman General Hospital, Southwest Ethiopia. J Nurs Care

http: // S1:003. doi:10.4172/2167-1168.S1-003

Beijaard, D., Meijer, P. C. \& Verloop, N. (2004). Reconsidering research on teachers' professional identity. Teaching and Teacher Education, 20, 107-128 
Black, S. (2012). When students push past peer influence. The Education Digest, $68,31-36$.

Chaun, O.L. \& Barnett, T. (2012). Student, tutor and staff nurse perceptions of the clinical learning environment. Nurse Education in Practice, 12(4): 192-197. $\quad$ http : // PMid:22277167 http://dx.doi.org/10.1016/j.nepr.2012.01.003

Crigger, N. \& Godfrey, N. (2012). FORMING a professional identity: an important key to nursing's future. Missouri nurse, 12-13.

Chan, D.S. (2003). Validation of the clinical learning environment inventory. Western Journal of Nursing Research; 25(5): 519-532. Available at :http://dx.doi.org/10.1177/0193945903253161

Den Brok, P., Van Tartwijk, J., Wubbels, T. \& Veldman, I. (2010). The differential effect of the teacher-student interpersonal relationship on student outcomes for students with different ethnic backgrounds. British Journal of Educational Psychology, 80(2), 199221.

Dunn, S. V., Ehrich, L., Mylonas, A. \& Hansford, B. (2000). Students' perceptions of field experience in professional development, a comparative study. Journal of advanced nursing education 39(9): 393-400.

Donald, A.M. (1996). Improving the quality of learning environment achieving a better partnership between academic staff and learning support staff in course delivery. UK

Fagermoen, M. (1997). Professional Identity: values embedded in meaningful nursing practice. Journal of Advanced Nursing, 25: 434-441.

Gray, M.A.\& Smith, L.N. (2000). The qualities of an effective mentor from the student nurses' perspective: findings from a longitudinal qualitative study. Journal of Advanced Nursing, 32(6): 1542-1549

Gamel, R. (2006). The image of nursing as a profession among undergraduate nursing students and interns. Unpublished Master Thesis, Faculty of Nursing: Alexandria University

Henning, M., Shulruf, B., Hawken, S. \& pinnock, R. (2011). Changing the learning environment: the medical student voice. The clinical teacher, 8 (2):83-87 
Kathleen, A. \& Colleen, M. (2013). Role of the staff nurse in undergraduate nursing education. American Nurse Today.www.AmericanNurseToday.com/

Kilcullen, N. (2007). Said Another Way. Nursing Forum, 2007, 42(2): 95-102.

Kroger, J. \& Marcia, J. (2011). The identity statuses: Origins, meanings, and interpretations. In: Schwartz, S., Luyckx, K., Vignoles, V. (eds), Handbook of Identity, Theory and Research. Springer, New York, pp. 31-53

Lo R. (2002). Evaluation of a mentor-arranged clinical practice placement for student nurses. Collegian, 9 (2), 27-32.

Lofmark, A. \& Wikblad, K. (2001). Issues and innovations in nursing education: Facilitating and obstructing factors for development of learning in clinical practice: a student perspective. Journal of Advanced Nursing, 34 (1), 43-50.

Musa, M. (2017) Opinions of secondary technical nursing school students about clinical learning environment and clinical supervision in Assiut city. Assiut University. Faculty of Nursing. Nursing Administration

McKenna, L., McCall, L. \& Wray, N. (2010). Clinical placements and nursing students' career planning: A qualitative exploration. Int. J. Nurs. Pract. 16(2):176-182

Midgley, K. (2006). Pre-registration student nurses perception of the hospitallearning environment during clinical placements. Nurse Education Today; 26: 338-345.

Meyer, E. \& Land, R. (2003). Threshold concepts and troublesome knowledge: linkages to ways of thinking and practicing within the disciplines. University of Edinburgh: ETL Project, School of Education

Murphy, F., Rosser, M. \& Bevan, R. (2012). Nursing students' experiences and preferences regarding hospital and community placements. Nurse Education in Practice;12(2012):170-175.Available at: $\quad$ http://dx.doi.org/10.1016/j.nepr.2011.12.007

Papp, I., Markkanen, M. , \& von Bonsdorff, M. (2003). Clinical environment as a learning environment: student nurses' perceptions concerning clinical learning experiences. Nurse Education Today, 23(4), 262-268. URL: http://www.sciencedirect.com/science/article/B6WNX-47CB9XW- 
Saleh, R. (2016) Professional Identity and Organizational Commitment among Nurses. Ain Shams University. Faculty of Nursing. Nursing Administration Department.

Saarikoski, M., Leino-Kilpi, H., \& Warne, T. (2010). Clinical learning environment and supervision: testing a research instrument in an international comparative study. Nurse Educ. Today 22 (4), 340-349.

Strayer, R. \& Beitz, J. (2010). Factors influencing pharmacology knowledge acquisition in traditional versus nontraditional baccalaureate nursing students: journal of professional nursing 26(5):301-308.

Saber, k. (1995). Influence of clinical educational environment on the development of professional identity on nursing students. (Unpublished doctoral thesis). Faculty of nursing, Alexandria University.

Taha, N. (2015). The relationship between learning environment and student satisfaction among nursing students' .port said university

Vågan, A. (2009). Medical students' perceptions of identity in communication skills training: a qualitative study. Med Educ.; 43(3):254-259.
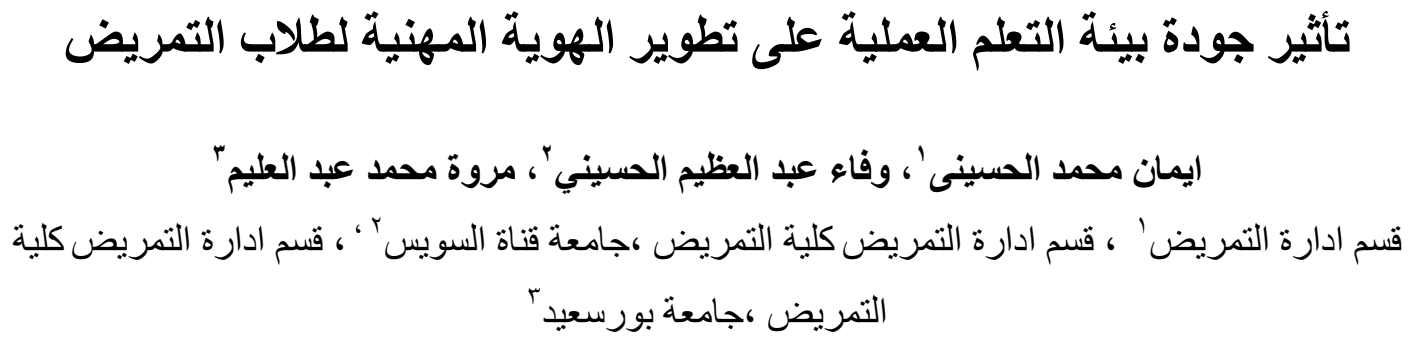

\section{الخلاصة}

لقد اصبحت الهوية المهنية واحدة من اهم التحديات فى تعليم التمريض. تهدف الدراسة الى دراسة تأثير بيئة التعلم العملية على تطوير الهوية المهنية لطلاب التمريض. وقد استخدم تصميم وصفى ارتباطى لتحقيق اهداف الدراسة . تمت الدر اسة في كلية التمريض جامعة بورسعيد واثنتلت علي جميع طلاب الفرقة الثالثة والر ابعة المتاحيين خلال فترة الدراسة ـ تم جمع البيانات باستخدام أداة واحده مقسمه الى ثلاثة اجز اء : استبيان للحصول على بيانات الطالب

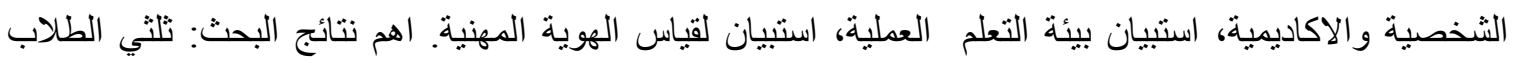

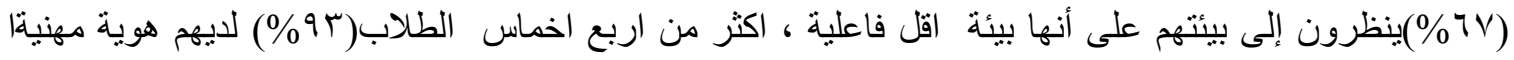
يجابية. وقد خلصت النتائج الي وجود علاقة ذات دلالة إحصائية بين بيئة التعلم العملية والهوية المهنية. على ضوء هذه النتائج أوصى الباحث بما يلي: زيادة الكلية المر افق التي تخلق بيئة تعليمية مناسبة و تشجيع عضو هيئة التدريس

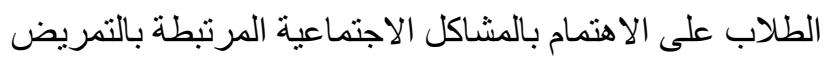

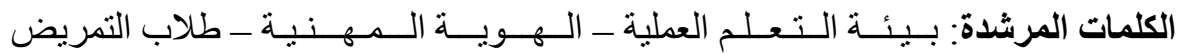

